E. Thorax-Herz-Gefä $\beta$-Chirurgie

\title{
121. Zum Zwerchfellersatz bei der radikalen Pleuropneumonektomie mit Zwerchfellresektion beim malignen Pleuramesotheliom
}

\author{
S. Geroulanos, P. Hahnloser und Å. Senning \\ Chirurgische Universitätsklinik A, Kantonsspital Zürich
}

\section{Reconstruction of the Diaphragm after Pleuropneumonectomy with Resection of the Whole Diaphragm for Malignant Pleural Mesothelioma}

\begin{abstract}
Summary. Seven out of 16 patients with malignant mesothelioma of the pleura underwent radical pleuropneumonectomy with resection of the whole diaphragm. Diaphragmatic replacement on the right side was achieved by fixation of the coronary ligament of the liver to the anterior thoracic wall and to the mobilized peritoneum of the retroperitoneal space. On the left side two methods allowed secure closure of the diaphragmatic defect: (A) Direct suture of the pericardial diaphragm to the thoracic wall after removal of several ribs; (B) Diaphragmatic replacement by a broad-pedicled left hemipericard. No serious complications were seen. The mean survival time after radical operation is $23(3-54)$ months with two patients still alive after 13 and 44 months. After palliative reduction of the tumor and explorative thoracotomy the mean survival times are $6(2-13)$ and 3 (1-6) months respectively. Pleuropneumonectomy with resection of the diaphragm only offers acceptable therapeutic results in patients with malignant mesothelioma of the pleura.
\end{abstract}

Key Words: Diaphragm - Pleura - Pneumonectomy - Mesothelioma.

Zusammenfassung. Sieben von 16 Patienten mit einem malignen Pleuramesotheliom konnten mittels Pleuropneumonektomie und Zwerchfellresektion radikal operiert werden. Der Zwerchfellersatz erfolgt rechts durch Fixation des mobilisierten Peritoneums an der Lamina dorsalis des Ligamentums coronarium hepatis. Die Lamina ventralis des letzteren wird an die vordere Thoraxwand genäht. Links wurden zwei Methoden angewendet: 1. Direktes Annähen der lateralen Thoraxwandanteile an die Pars pericardiaca diaphragmatis, was durch Resektion mehrerer Rippen ermöglicht wurde. 2. Verschluß der unteren Thoraxapertur durch einen breit gestielten Perikardlappen. Die mittlere Úberlebenszeit nach radikaler Pleuropneumonektomie beträgt 23 Monate (3-54 Monate) - wobei 2 Patienten 13 bzw. 44 Monate nach dem Eingriff noch am Leben sind - nach palliativer Resektion 6 Monate (2-13 Monate) und nach Probethorakotomie 3 Monate (1-6 Monate).

Schliisselwörter: Zwerchfell - Pleura - Pleuropneumonektomie - Mesotheliom. 